\title{
Spray Dosing Unit
}

National Cancer Institute

\section{Source}

National Cancer Institute. Spray Dosing Unit. NCI Thesaurus. Code C48537.

A dosing unit equal to the amount of active ing redient(s) contained in a spray. 